Jules Vuillemin (15 ${ }^{\text {th }}$ February 1920 - $16^{\text {th }}$ January 2001)

Author(s): Joseph Vidal-Rosset and Karel Lambert

Source: Dialectica, Vol. 55, No. 1 (2001), pp. 3-7

Published by: Wiley

Stable URL: http://www.jstor.org/stable/42970777

Accessed: 14-06-2017 08:07 UTC

JSTOR is a not-for-profit service that helps scholars, researchers, and students discover, use, and build upon a wide range of content in a trusted digital archive. We use information technology and tools to increase productivity and facilitate new forms of scholarship. For more information about JSTOR, please contact support@jstor.org.

Your use of the JSTOR archive indicates your acceptance of the Terms \& Conditions of Use, available at http://about.jstor.org/terms

Wiley is collaborating with JSTOR to digitize, preserve and extend access to Dialectica 


\section{Jules Vuillemin}

(15 $5^{\text {th }}$ February $1920-16^{\text {th }}$ January 2001)

Jules Vuillemin died on January $16^{\text {th }}, 2001$. He was nearly 81 . In France, his work influenced mainly philosophers of science. Though he did not aspire to press popularity, he was recognized throughout the world as an important and profound philosopher, gifted with an uncommon knowledge of the history of science and the history of philosophy. He wrote with a simple but austere style, and expressed clear judgments in incisive sentences; his philosophical style was without slogans. His wide group of international friends were chagrined if not surprised that he became, in his own words, "a stranger in my own country."

Vuillemin was convinced philosophical work draws its value from the way it gives replies to the classical problems. The profound and original character of his work - though known to, and respected by, many prestigious philosophers around the world - is not very widely known in England or in the U.S.A. No doubt his public reputation would have been much greater had he chose to define himself as a positivist or an analytic philosopher. But he did not identify himself with any of the fashionable isms of his time and sought only to "find what is true" by dint of close and rigorous thinking. In this respect, his attitude toward philosophy resembled most closely, perhaps, the late American philosopher Roderick Chisholm, though his views, interests and methods were very different. He said of himself that he was born a skeptic, but he did not believe in the philosophy of skepticism.

His philosophical mentor was Martial Gueroult, who sponsored him and brought about his election to the prestigious Collège de France, in 1962, as the successor to Merleau-Ponty. Vuillemin was only 42 years old when he was elected to the Collège de France (the French equivalent of the Institute for Advanced Studies at Princeton.) He retired in 1990. Before this election, Vuillemin's academic history was as classical as it was brilliant. Beginning at the Lycée Louis le Grand in Paris, he went next to the Ecole Normale Supérieure, agrégation of philosophy. After a short stay as Professor in the 
Lycée he was named to a chair at the University of Clermont-Ferrand, where he lived until 1962.

During the war he joined his village resistance group in 1943. The dramas of the Second World War had an important influence on his his life. He confessed that he always worked with a of feeling of urgency. Few people knew that he wrote Trois histoires de guerre (Three short war stories); they were published in 1991, at Besançon. These short stories belong to the second and the last period of Vuillemin's literary work. Le Miroir de Venise, in 1965, was the first.

His philosophical development can be divided into three periods. In the first stage he dealt with existential questions. (Le sens du destin, 1948, coauthored with Louis Guillermit; Essai sur la signification de la mort, 1948, L'être et le travail, 1949; and the profound L'héritage kantien et la révolution copernicienne, 1954). The second period began in 1955 when he published Physique et Métaphysique kantienne, and five years later Mathématiques et métaphysiques chez Descartes. Of this period Vuillemin said

Up to this point, I had worked without a specific method. I asked Descartes and Kant to reveal theirs to me. I noticed that their views remained scarcely intelligible and sometimes impenetrable if one did not go back to the sciences which had inspired them or which they had created. ${ }^{1}$

Vuillemin never denied the importance of science to philosophy. That is why, after his wonderful study on the Philosophy of the Algebra (Introduction à la philosophie de l'algèbre, 1962), he gave fastidious attention to the role of logic in Aristotle's and Russell's philosophical systems. From these reflections arose De la logique à la théologie, cinq études sur Aristote, (1967), Leçon sur la première philosophie de Russell, (1968).

He was among the first French philosophers to recognize the importance of logical positivism and the development of rigorous methods in analytic philosophy. Among the analytic philosophers and logicians he caused to be invited to give lectures or lecture series at the Collège de France were W.V. Quine, P.F. Strawson, P. Suppes, R. Marcus and K. Lambert. But he never admitted that mathematical logic alone would suffice alone as a basis for what he called "a philosophical system," and he never found agreement with what he took to be the Quine-Lambert thesis that there is no difference in principle between scientific and philosophical theories. Three of Vuillemin's books demonstrate that he considered seriously the benefits mathematical logic could

1 "Ma vie en bref", in Causality, Method and Modality, Essays in Honor of Jules Vuillemin, Gordon Jr. Brittan ed., Kluwer Academic Publishers, Dordrecht, 1991. 
have for philosophy: Le Dieu d'Anselme et les apparences de la raison (1971), La logique et le monde sensible (1971), and Mérites et Limites des méthodes logiques en philosophie (1986), this last one being the only book that Vuillemin did as editor of a conference he had organized.

The third, and final, phase of Vuillemin's work resulted in three books that reflect his own mature philosopy: Nécessité ou contingence (1984 - the first part being translated with corrections in English: Necessity or Contingency, CSLI Lecture Notes $\mathrm{n}^{\circ} 56$, Stanford, 1996), What are philosophical systems? (Cambridge University Press, 1986) and Eléments de Poétiques (1991) in which he presented his reflections on aesthetics. In What are philosophical systems?, perhaps his major philosophical treatise, Vuillemin presented a profound analysis of classical philosophical systems as all based on the privileged treatment each gives to a single elementary sentence (from a list of five main types of elementary sentences of the natural language). This led him to an a priori classification of philosophical systems. In this book, he showed where he disagreed with opinions he took as belonging to analytic philosophy. He wrote in the preface:

\begin{abstract}
I deny in the first chapter that language shapes perception, since perception precedes language. In the second chapter, despite the relative autonomy of linguistic organization with respect to perceptual organization and though its collective conceptual stability expresses and embodies, for each particular society, a determinate Weltanschauung, i.e. a collective code of classification, I deny that a Weltanschauung is a Philosophy, since publicity entails neither consistency nor a wish for consistency. In the third chapter, because Philosophy and Science have a common origin in the discovery of antinomies and in the development of axiomatics, I deny that strong continuity between Philosophy and common sense which is advocated by many philosophers of natural language. Finally, when in the last chapter I arrive at the question of philosophical truth, I give my fellow philosophers the slip and let them go further than I do. While they argue for a unique scheme of philosophical truth, I am content to say what all of the possibilities of truth are. ${ }^{2}$
\end{abstract}

According to this understanding of philosophical systems, Vuillemin declared himself to be a real pluralist in philosophy, "maybe the only one in the world", he used to joke. But in this classification, Vuillemin made a real and rational choice. He adopted a genuine Platonism, with a belief in an intelligible world, transcendent to the world of matter, the former being indispensable to understanding the latter. In his last papers, he tried to show that Gödel was right to deny Carnap's conventionalism in mathematics:

Let us give back to the world of logic the restricted and natural meaning which was its own in the completeness theorem, while maintaining the whole of mathematics. Then it seems to be required that the intelligible world does exist. ${ }^{3}$

2 What are philosophical systems?, C.U.P:, London, 1986.

3 "La question de savoir s'il existe des réalités mathématiques a-t-elle un sens?", Philosophia Scientiae, Vol. 2, Cahier 2, 1997, p. 276. 
This opinion he believed to conflict with much analytic philosophy. First, Vuillemin argued, genuine Platonism is not a set of scientific truths, nor can it be proved to be so, because other choices are possible. (He said he was as unable to prove that Carnap was wrong in his philosophical reading of Gödel's theorem, as was Plato to refute Protagoras.) Second, he adopted Platonism in both science and ethics and believed that The Good and Justice have a reality that can be known by pure Reason. He was not an empiricist, but respected some expressions of empiricism; he disliked especially relativist sociologies.

Vuillemin wrote many philosophical papers; they were usually deep, and always enlightening. It is impossible to list them all here. ${ }^{4}$ It is also impossible to capture the man by mentioning only his academic work.

Vuillemin, the person, tended to be conservative politically, but socially was very affable. Though fixed in his likes and dislikes, he had a wonderful sense of humour, and, with his wife Gudrun, enjoyed entertaining his friends (and their children) at his retreat in Les Fourgs. He was courtly, without being stiff, and decisive without being offensive. And he was not beyond rescuing a friend, even if a philosopher, from potentially damaging social situations, for example, by substituting a glass of wine for a Coca Cola during a friend's lecture at the Collège de France. On the other hand, he knew he was an easy mark, especially to children - and he loved it. For example, at first incredulous that moles could be chased away by putting little wind-mill sticks in their tunnels, as the son of one of his friends insisted, he was astonished and delighted to find out that the boy's claim was true! On another occasion he was at lunch with a student. In front of them was a classified bottle of Bordeaux. The student said, "Here is a useful classification at least", suggesting, by implication, that Vuillemin's classification of philosophical systems might be far less useful in comparison. Vuillemin laughed heartily and, remembered out loud that he had done something of the same to his old teacher Gueroult. He was also given to pungent responses. Once, a scholar who had been invited to the Collège de France from California, sent him an article by an anti-California columnist from Chicago. The columinist had written that putting a very high brick wall around that strange state was insufficient to isolate Californians because "they could just wave their arms and fly over the wall". Vuillemin replied immediately by telegram, "Does this mean that the College de France doesn't have to pay your plane fare?"

${ }^{2}$ For a complete bibliography of Jules Vuillemin, complete in 1991 only, see Causality, Method and Modality, Essays in Honor of Jules Vuillemin, Gordon Jr. Brittain ed., Kluwer Academic Publishers, Dordrecht, 1991. 
Those who knew him treasured his friendship. He said: "For me words really mean something, but it is not enough merely to express one's strong commitment to friendship." A devoted father (and grandfather), he also enjoyed his isolation. Until five or six years before his death, he lived without a phone, but always replied to the letters he received. He dutifully would read the book, essay, or letter of a friend or of a correspondent with real attention before writing back. As teacher, he was unbelievably generous and friendly. As a colleague he was diligent, forthright and honest, and as a thinker, it is proper to point out here, as so many outside his country often did, that he was during his lifetime France's greatest philosopher and historian of science.

Joseph Vidal-Rosset Karel Lambert 